\title{
Genetic diversity assessed in individuals of Aspidosperma polyneuron and Cariniana estrellensis used as seed donors in an forest gene bank
}

\author{
Ana Lilia Alzate-Marin ${ }^{1}$, Ronai Ferreira-Ramos ${ }^{2 *}$, Marcela Guidugli ${ }^{1}$, Carlos Alberto Martinez ${ }^{3}$, \\ Moacyr Antonio Mestriner ${ }^{1}$
}

From IUFRO Tree Biotechnology Conference 2011: From Genomes to Integration and Delivery Arraial d'Ajuda, Bahia, Brazil. 26 June - 2 July 2011

\section{Background}

The neotropical tree species Aspidosperma polyneuron and Cariniana estrellensis, known as peroba-rosa and jequitibá-branco respectively, are characteristic of late secondary semideciduous Atlantic forest in submontane formation. Their wood is widely used for carpentry and construction. Increasing logging, intensive agriculture and urban expansion placed A. polyneuron in the Red List of Threatened Species [http://www.iucnredlist.org/ apps/redlist/details/32023/0] while C. estrellensis is considered an endangered species. So, in situ conservation of these forest species is critical while ex situ collections as gene banks is an important complementary approach. Our study assessed and compared the genetic diversity of A. polyneuron and C. estrellensis in two stands aiming to provide subsidies for the ex situ conservation of these important genetic resources.

\section{Material and methods}

Leaf tissues of mature trees of two disturbed stands (SI and SII) of A. polyneuron and C. estrellensis were sampled and stored at $-20^{\circ} \mathrm{C}$ : SI was composed by isolated individuals of an extensive area located among Pardo river and Mogi-Guaçu river basins used as seed donor of a Forest Genetic Bank, at the University of São Paulo in Ribeirão Preto campus (BG-USP/RP), SP-Brazil. SII was one of the last natural populations around Ribeirão Preto region of an isolated fragment of 7.5 ha

\footnotetext{
* Correspondence: ronai1977@yahoo.com.br

${ }^{2}$ Programa de Pós-Graduação em Biologia Comparada, Departamento de Biologia, FFCLRP/USP, Brazil

Full list of author information is available at the end of the article
}

located on Águas Claras farm in Cravinhos Municipality $\left(21^{\circ} 17^{\prime} 47^{\prime \prime} S\right.$; 47 $\left.40^{\circ} 29^{\prime \prime} \mathrm{W}\right)$.

DNA extraction was performed according to [1]. SSR markers development for C. estrellensis[2] and for $A$. polyneuron (Ferreira-Ramos R., unpublished)] were used for this study (Tables 1,2). Microsatellite loci were amplified individually according [3]. FSTAT software [http://www2.unil.ch/popgen/softwares/fstat.htm] was used to calculate the genetic parameters per locus and sample: mean number of alleles $(A)$, the observed $\left(H_{o}\right)$ and expected heterozygosities $\left(H_{e}\right)$. Wright's fixation index was calculated as $1-H_{o} / H_{e}$. Deviation from Hardy-Weinberg equilibrium (HWE) was measured using GDA software[http://hydrodictyon.eeb.uconn.edu/ people/plewis/software.php].

\section{Results and discussion}

For both species, the genetic diversity was higher in SI than SII $\left(H_{e}\right.$ SI $/ S I I=0.65 / 0.47, H_{e}$ SI $/ S I I=0.72 / 0.61$ for $A$. polyneuron and C. estrellensis, respectively). For A. polyneuron, the expected heterozygosity $\left(H_{e}\right)$ was higher than observed heterozygosity $\left(H_{o}\right)$ in SI and SII. For $C$. estrellensis $H_{e}$ was higher than $H_{o}$ in SI and the opposite was found in SII. Fixation index was higher in SI than SII for both species $\left(\mathrm{F}_{S I / S I I}=0.30 / 0.11, \mathrm{~F}_{S I / S I I}=0.29 /-0.05\right.$ for A. polyneuron and C. estrellensis, respectively), suggesting inbreeding. Significant departures from HWE were observed for most loci in both species mainly in SI, which might be due to population substructure (Wahlund effect).

In summary, our study revealed a high diversity for the seed donor trees of A. polyneuron and C. estrellensis 
(SI), suggesting that this diversity was incorporated into BG-USP/RP. Indeed future progeny studies will be able to confirm these results. The low diversity found in SII for A. polyneuron highlights its threatened situation in this stand, on of the last natural populations in Ribeirão Preto (SP-Brazil). For C. estrellensis, a higher genetic diversity was observed which may be due to greater number of trees in the population, preferentially outcrossed mating system and probably gene flow from outside the fragment studied.

Financial Support: FAPESP, CNPq, CAPES-PROEX, FAEPA

\section{Author details}

'Departamento de Genética, FMRP, Universidade de São Paulo, Ribeirão Preto, SP, Brazil. ${ }^{2}$ Programa de Pós-Graduação em Biologia Comparada, Departamento de Biologia, FFCLRP/USP, Brazil. ${ }^{3}$ Departamento de Biologia, FFCLRP/USP, Brazil.

Published: 13 September 2011

\section{References}

1. Alzate-Marin AL, Guidugli MC, Soriani HH, Martinez CAH, Mestriner MA: An efficient and rapid DNA minpreparation suitable for PCR/SSR and RAPD analysis in tropical forest tree species. Braz Arch Biol Technol 2009, 52:1217-1224.

2. Guidugli MC, Campos T, Sousa ACB, Feres JM, Sebbenn AM, Mestriner MA Contel EPB, Alzate-Marin AL: Development and characterization of 15 microsatellite loci for Cariniana estrellensis and transferability to Cariniana legalis, two endangered tropical tree species. Conserv Genet 2009, 10:1001-1004.

\section{doi:10.1186/1753-6561-5-S7-P8}

Cite this article as: Alzate-Marin et al:: Genetic diversity assessed in individuals of Aspidosperma polyneuron and Cariniana estrellensis used as seed donors in an forest gene bank. BMC Proceedings 2011 5(Suppl 7): P8.

\section{Submit your next manuscript to BioMed Central} and take full advantage of:

- Convenient online submission

- Thorough peer review

- No space constraints or color figure charges

- Immediate publication on acceptance

- Inclusion in PubMed, CAS, Scopus and Google Scholar

- Research which is freely available for redistribution

Submit your manuscript at www.biomedcentral.com/submit 